\title{
Testing Profit and Loss Sharing to Stabilise Level of Inflation: Evidence From Indonesia
}

\author{
Ghozali Maski $^{1}$, An'im Kafabih ${ }^{1}$ \& Arif Hoetoro ${ }^{1}$ \\ ${ }^{1}$ Faculty of Economics and Business, Brawijaya University, Indonesia \\ Correspondence: An'im Kafabih, Faculty of Economics and Business, Brawijaya University, Indonesia.
}

Received: August 19, 2018

Accepted: September 4, 2018

Online Published: November 8, 2018

doi:10.5430/rwe.v9n2p12

URL: https://doi.org/10.5430/rwe.v9n2p12

\begin{abstract}
The objective of this research is for testing whether profit and loss sharing (PLS) can stabilise inflation compared to interest rate. By using ARDL bound test with monthly data from January 2012 to May 2016, the result shows that PLS that is proxied by national sukuk, mudharabah and musharakah and interest rate simultaneously can affect inflation in Indonesia. Based on coefficient value analysis, PLS that is proxied by national sukuk can stabilise level of inflation in the long run only. Musharakah as other proxy of PLS can stabilise inflation in the short run only. However, mudharabah cannot be used to stabilise inflation both the short run and long run.
\end{abstract}

Keywords: profit and loss sharing, inflation, interest rate, ARDL bound test

\section{Introduction}

Fundamental determinant of human welfare is consumption of goods and services (Deaton, 2015). Therefore, stable level of inflation as a proxy of human welfare is important to assure the ones can afford to buy their necessities. Furthermore, Indonesia government authorizes Bank of Indonesia the main objective to maintain and achieve stability of rupiah value against goods and services which is reflected by the rate of inflation.

Start from 1999, Bank of Indonesia (BI) has been adopting inflation targeting to stabilise price by influencing expectation of inflation and coordinating with government (Kenward, 2013). However, based on data publised on official BI's website from 2001 to 2016, BI has failed to achieve inflation in target range for 11 times and 6 of it is higher than target range that has been set. In addition, some economist such as Blanchard (1997) explained that stable price is zero inflation. Kunio Okina, ex-director at the Bank of Japan, in Nishizaki and Watanabe (2000) and Hoover (2012) also argued that zero level of inflation is an optimal target for monetary policy. However, based on BI monthly data as depicted in Figure 1 below, Indonesia never achieve zero inflation or event near zero inflation yet.

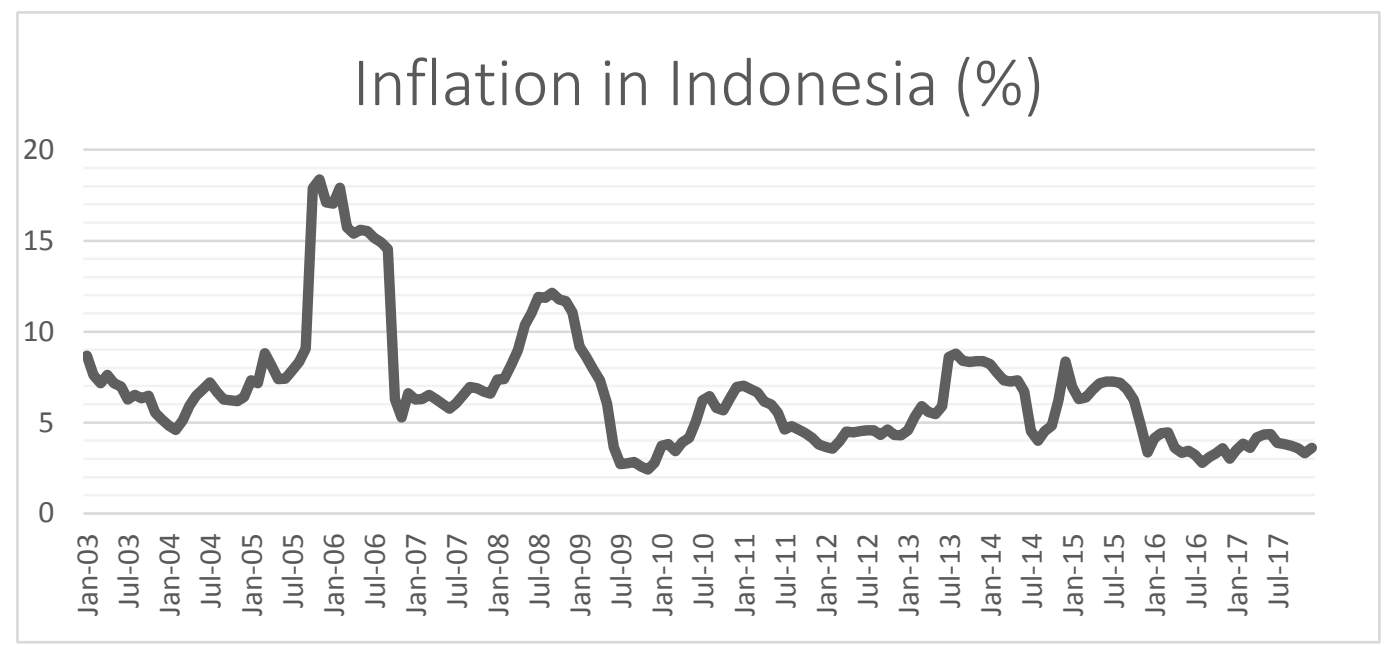

Figure 1

Source: Bank of Indonesia, 2018 (Processed with MS Excel 2013). 
The chart above depicts the fluctuation movement of inflation in Indonesia. It also delineates that Indonesia never gain stable price in the form of zero inflation or even near-zero inflation. The lowest rate of inflation ever gained is $2.41 \%$ in November 2009, and there is no increasing level of inflation at the rate of $2 \%$ or even $1 \%$, nor $0 \%$. Moreover, at that observed period, the highest rate of inflation is $18.38 \%$ in November 2005.

Zero inflation definition as a form of price stability is still debatable. Aiyagarin (1990)'s study showed that shifting inflation to zero will lead to higher cost than benefit, Nishizaki and Watanabe (2000) also argued that Phillips curve become flatter at the rate of inflation approaches zero, making inflation very sensitive to unemployment. However, other study such as Sunel (2018) shows that disinflation will increase welfare, Wolman (1997) shows that as inflation reduce from 5 per cent to zero, the consumption of output will increase by 0,6 percent.

Suhariyanto, head of Indonesian Statistics, said that for the first time since 1999 Indonesia unemployment rate decline to 9,82 per cent or one digit under 10 per cent (Note 1). However, if inflation is not maintained to be stable, that achievement will be meaningless since inflation will reduce purchasing power of citizen. Meaning that eventhough unemployment rate decline because of the rise of income, there will be meaningless as inflation also rise because it will "tax" income and reduces citizen's ability to buy something. Therefore, its important to make inflation in Indonesia to be stable.

Chishti (1985) in his study explained that Profit and loss sharing (PLS) will make investment more stable compared with advanced capitalist economy that uses interest rate. If this argument is related to aggregate demand theory, then investment under PLS will bring more stable inflation in the long run rather than investment under interest rate. Therefore, the main objective of this study is to investigate the relation of PLS and also interest rate to inflation in Indonesia.

The next chapter of this paper will present the theoretical background that explains on how PLS can stabilise investment rather than interest rate and also review some previous researches on the topic. Next chapter will explain research method in this paper, then result and discussion of the finding will be presented, and the last is conclusion.

\section{Theoretical Background}

\subsection{Inflation}

Inflation is a general and ongoing rise in the level of price in an entire economy (Openstax, 2014), but not refer to relative price since relative price is the price of goods relative to other goods (Mankiw, 2012). In historical aspect, the early history about inflation measurement according to O'neill, Ralph and Smith (2017) can be tracked in the 1700-1879 because from 1880 onward, official organisations had formalised and managed data collection. The conclusion of that data then were used for political decision making which same as practice in modern era (O'neill, Ralph and Smith, 2017).

inflation can be measured based on Consumer Price Index (CPI) and/or GDP deflator. CPI measures the retail price of a "fixed market basket" of several thousand goods and services purchased by household (Froyen, 2013). Deflator GDP or implicit price deflator for GDP is the ratio of nominal GDP to real GDP, a measurement of overall level of price that shows the cost of the currency produced basket of goods relative to the cost of that basket in a base year (Mankiw, 2012).

Basically, aggregate demand tries to conceptualise monetary and fiscal policy that will affect to both output and general price. Some instruments that included to monetary policy is money supply, and for fiscal policy is governmrnt expenditure and taxation with the assumption of closed economy. Furthermore, as the aggregate demand swift outward, this will lead to increasing output in the short run, and followed by the rise of general price (inflation) in the long run.

\subsection{Relative Stability on Profit and Loss Sharing}

Chishti (1985) in his paper "the relative stability of interest-free economy" explained on how PLS can stabilise investment rather than interest rate. The main idea of his notion is that under Islamic financial system, the amplitude of business cycles (euphorism or booming condition and pessimism or recession condition) which are inherent characteristics of advanced capitalist economy will be smaller (Chishti, 1985). For simplicity, Chishti (1985)'s notion can be illustrated in the graph below. 


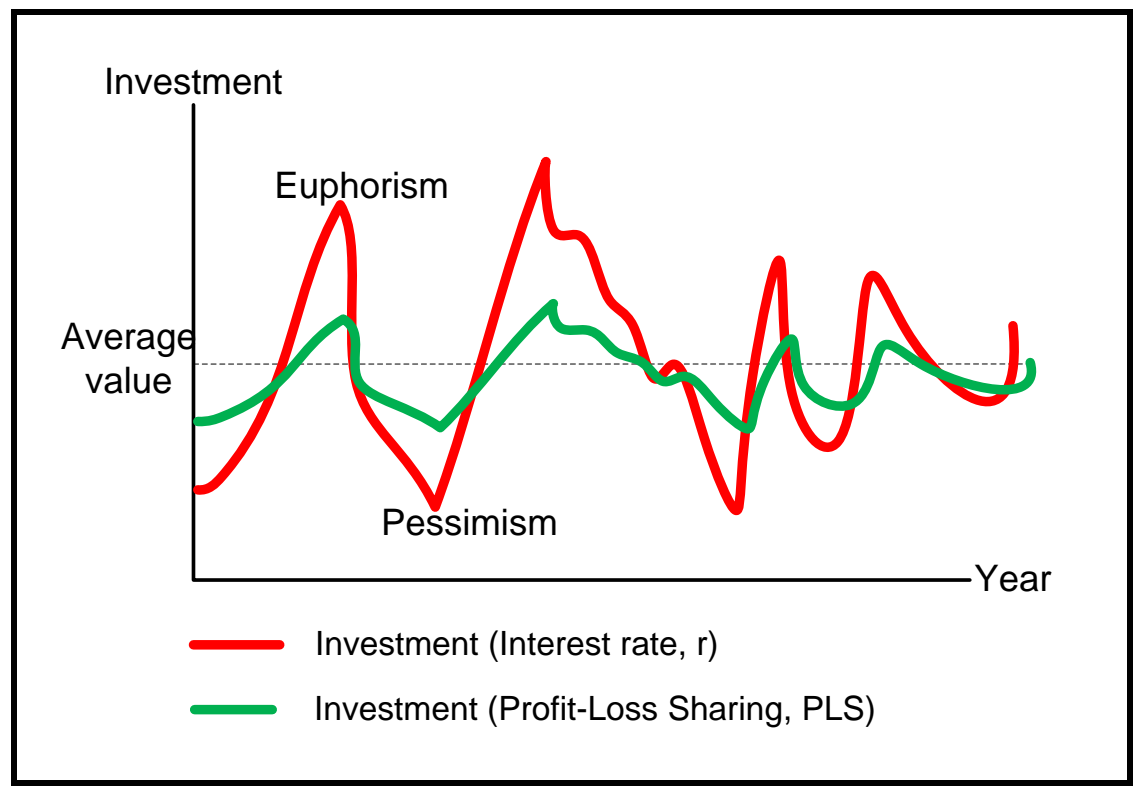

Figure 2. Investment under interest and PLS

Source: Researcher's own illustration adopted from Chishti (1985)'s explanation.

Assuming that this kind of investment is money that is borrowed or lended (with interest or PLS scheme) to be used to buy equipment and other structures in production (synthesis from Mankiw, 2012), as depicted in the graph above, the red line depicts euphorism or booming condition and also pessimism or recession condition in advanced economy. Chishti (1985) claimed that the high fluctuation in the red line investment is because of fixity of the dated payment commitment (payment of interest and principal in investment) whereas profit is uncertain. Chishti (1995) argued that if the uncertainty of profit is linked to payment commitment (by using PLS) in a way that they move together, the investment will be more stable rather than very fluctuative (depicted in the green-line of above graph).

Starting from the sharp increase of red-line investment. this happens because of euphoric economic condition in business cycle that lead profit to be predicted to significantly increase more that payment commitment. This underlying condition makes investment increase sharply that is signed by many investors lending their money because they see potency of higher return if they invest in the booming condition.

In the sharp decrease of red-line investment, profit is predicted to significantly go down under payment commitment. Investment will be almost stop because of many bankruptcies, and capital loss and at the same time borrowers still have to pay its commitment (interest and principal). This condition lead investors will not lending their money and making investment rate significantly go down.

However, under Profit and Loss Sharing (PLS), all phases of business cycle the amplitude would be smaller (Chishti, 1985). This because of PLS accomodates uncertainty of profit that will or will not be gained in both two business cycle condition. Therefore, in the booming period, investment in PLS scheme is less than based on interest rate. Likewise in the recession period, PLS still makes investment reduce but not much higher than investment from interest rate.

Then,continuing the above explanation with concept of aggregate demand, the fluctuation of investment shifting the IS curve and affecting to aggregate demand curve upward or downward, then in the long run fill affect to general price level. Based on Chishti's (1985) theory then, investment that based on interest rate will more fluctuative compared to investment under profit and loss sharing. Therefore, in the long run, fluctuation of general price will be more stable under investment that based on PLS rather than interest rate. Ascarya (2017) showed that PLS can be used to cure financial crisis that is proxied by economic growth and inflation. Ariff (2015) explained that the of sukuk can tame debt. As sukuk is under PLS, this argument support Chishti (1985)'s theory. Krishnamurthy, Pelletier, and Warr (2018) also show that equity and mutual fund can be used to make inflation lower. 


\subsection{Interest Rate on Inflation}

in Fisher effect, a 1 percent increase in the rate of inflation causes a 1 percent increase in nominal interest rate (Mankiw, 2012). Anari and Kolari (2016) explained the causality process in Fisher theory where the positive relation for one to one relationship between nominal interest rate and expected inflation comes firstly from inflation rate to interest rate. However, Anari and Kolari (2016) also explained the other perspective that comes from Wicksell theory where inflation and interest rate has negative relationship and for causality process, they comes firstly from interest rate to inflation, meaning that an increase in the rate of interest will decrease the rate of inflation, the invers of Fisher theory.

Lee (2007) found the positive relation between nominal interest rate and inflation while rejecting the notion of a full Fisher effect. Demary and Hutler (2015) also explains that the low level of inflation is becasue of low equilibrium of real interest rate and under full employment and stable price with combination of zero lower bound on nominal interest rate. Other studies such as Booth and Ciner (2001), and Linnemann (2005) also find the positive relation between interest rate on inflation.

\section{Research Method and Data}

\subsection{Data}

This paper uses quantitative approach. Profit and loss sharing (PLS) is proxied by national sukuk; mudharabah and musharakah since these variables also use PLS sheme in its akad. Interest rate is proxied by BI rate, and inflation is proxied by consumer price index (CPI). All data are gathered from Bank of Indonesia for BI rate and national sukuk, mudharabah and musharakah, are gathered from Financial Services Authority (Otoritas Jasa Keuangan). The data are monthly time series from January 2012 to May 2016. Statistical tool that is used in this research is autoregressive and distributed lag (ARDL) bounds test approach developed by Pesaran, Shin and Smith (2001) (Known as PSS).

The advantage of this approach is that it applicable to a set of time series albeit series are $\mathrm{I}(0)$ and/or $\mathrm{I}(1)$ or in other words, the ARDL method was shown to work regardless of the order of integration the time series under consideration (Rushdi, Kim, and Silvapulle, 2012). Other advantage of this method is that it is more robust and performs better for small sample size than other co-integration technique ( Akmal, 2007). Following Omar, Hussin, and Ali GH (2015), by using this approach, there are two hypotheses that will be examined. The first is to examine the long run relationship simultaneously (co-integration), and the second to study long run and short run for each of variables. The hypotheses of this research can be written in the table below (Omar, Hussin, and Ali GH, 2015).

Table 1. Research hypotheses

\begin{tabular}{cl}
\hline $\mathbf{H}$ & \multicolumn{1}{c}{ Research Hypotheses } \\
\hline $\mathbf{H - 1}$ & $\begin{array}{l}\text { General level relation } \\
\text { There is a general level relation between profit and loss sharing (proxied by national } \\
\text { sukuk; mudharabah and musharakah) and controlled variable (Interest rate) on } \\
\text { inflation }\end{array}$ \\
\hline & $\begin{array}{l}\text { Partial level relation } \\
\text { National sukuk affects inflation in the long run }\end{array}$ \\
$\mathbf{H - 2} \quad \begin{array}{l}\text { Mudharabah affects inflation in the long run } \\
\text { Musharakah affects inflation in the long run } \\
\text { Interest rate affects inflation in the long run }\end{array}$
\end{tabular}

Source: Researcher, 2018

\subsection{Model Specification and Research Method}

Akmal (2007) explained that the underlying statistic of ARDL bounds test approach is familiar wald or F-statistics in a generalized Dickey-Fuller type regression which is used to test the significance of lagged variable under unrestricted equilibrium error correction model (ECM). Following Acaravci, Acaravci, and Ozturk (2011) to re arrange model in this research, model specification below is used to examine hypothesis H-1 or the existence of long run relationship among variables simultaneously. 


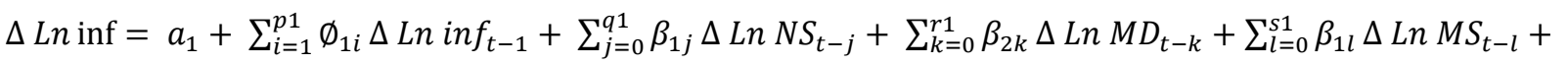

$$
\begin{aligned}
& \sum_{m=0}^{t 1} \beta_{1 m} \Delta \operatorname{Ln} \text { BIRATE }_{t-m}+\partial_{1} \operatorname{Lninf}_{t-1}+\partial_{2} L n N S_{t-1}+\partial_{3} \operatorname{Ln} M D_{t-1}+\partial_{4} L n M S_{t-1}+ \\
& \partial_{5} \operatorname{Ln} B \operatorname{RITAE} E_{t-1} \varepsilon_{1 t}
\end{aligned}
$$

Taking Ln for natural $\log , \varepsilon_{1 t}$ and $\Delta$ stand for the white noise term and the first difference operator respectively, inf is inflation; NS is National Sukuk and MD is mudharabah, MS is musharakah, and BIRATE is interest rate. The Null hypothesis for no cointegration (non-existence of long-run relationship) for variable inf against alternative hypothesis is given as:

$$
\begin{aligned}
& \mathrm{H}_{0}: \partial_{1}=\partial_{2}=\partial_{3}=\partial_{4}=\partial_{5}=0 \\
& \mathrm{H}_{\mathrm{a}}: \partial_{1} \neq \partial_{2} \neq \partial_{3} \neq \partial_{4} \neq \partial_{5} \neq 0
\end{aligned}
$$

Omar, Hussin, and Ali GH (2015) explained for testing the above hypothesis by using the F-statistics where if the computed F-statistics is higher than upper bounds critical value, then null hypothesis will be rejected which means there are long-run relationship between government revenue and government debt to Inflation simultaneously.

After equation 1 of long run co-integration test model is computed, Acaravci, Acaravci, and Ozturk (2011) explained that if any evidence of long run relationship (cointegration), the next step is estimating the following long run and short run models respectively to test hypothesis $\mathrm{H}-2$.

$$
\begin{aligned}
& \operatorname{Ln} \inf _{t}=a_{2}+\sum_{i=1}^{p 2} \emptyset_{2 i} \operatorname{Lninf}_{t-i}+\sum_{j=0}^{q 2} \beta_{2 j} \operatorname{Ln} N S_{t-j}+\sum_{k=0}^{r 3} \beta_{3 k} \operatorname{Ln} M D+\sum_{l=0}^{s 4} \beta_{3 l} \operatorname{Ln} M S+ \\
& \sum_{m=0}^{t 5} \beta_{3 m} \operatorname{Ln} \text { BIRATE }+\varepsilon_{2 t}
\end{aligned}
$$

equation 2

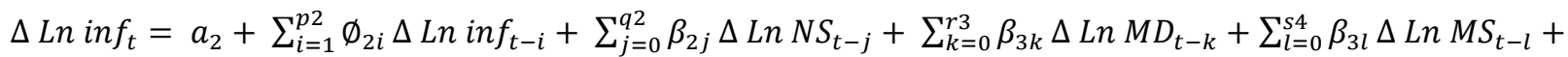

$$
\begin{aligned}
& \sum_{m=0}^{t 5} \beta_{3 m} \Delta \operatorname{Ln} B I R A T E_{t-m}+\Psi E C T+\varepsilon_{2 t}
\end{aligned}
$$

$\Psi$ is the coefficient of error correction term (hereafter ECT). It shows how quickly variables converge to equilibrium and it should have a statistically significant coefficient with a negative sign (Acaravci, Acaravci, and Ozturk, 2011). before proceeding ARDL bound test, as explained by Akmal (2007) and Obradovic et al (2017), unit root testing will be used for avoiding the possibility of certain variables being of the order I (2) or higher. This because if any presence of I (2) variables, the computed F-statistics are not valid because bounds test is based on the assumption that the variables are I(0) or I(1) (Akmal, 2007). Then after testing for Unit Root, Akaike information Criterion (AIC) is employed to determine optimal lag length of $\operatorname{ARDL}(p, q, r)$ as proposed by Gujarati and Porter (2009).

Then the last, as Gujarati and Porter (2009) explained that time series data may have not the same parameter of the model through the entire time period, or known as structural change, Shahbaz, Islam and Rehman (2016), and Bahmani Oskooee and Kanitpong (2017) proposed CUSUM and CUSUM sq test for the stability of the long run and short run coefficient because of any structural change in the period. The table below resume variables in this research.

Table 2. Variables in this research

\begin{tabular}{llll}
\hline Variable & Definition & Proxy & Source of Data \\
\hline Inflation (Inf) & $\begin{array}{l}\text { a general and ongoing rise in the } \\
\text { level of price in an entire economy }\end{array}$ & $\begin{array}{l}\text { percentage change of } \\
\text { CPI from bank of } \\
\text { Indnesia January 2012 - } \\
\text { May 2016 }\end{array}$ \\
\hline $\begin{array}{l}\text { National } \\
\text { (NS) }\end{array}$ & Sukuk & $\begin{array}{l}\text { National Sukuk is shari'ah bond } \\
\text { which is issued according to SBSN } \\
\text { shari'ah principle (Mudharabah, } \\
\text { Musyarakah, and others). (The Law }\end{array}$ & $\begin{array}{l}\text { bank of Indnesia } \\
\text { January 2012 - May }\end{array}$ \\
\hline
\end{tabular}




\begin{tabular}{|c|c|c|c|}
\hline & Number 19, year 2008). & & \\
\hline Mudharabah (MD) & $\begin{array}{l}\text { form of partnership where one of } \\
\text { the contracting parties, called the } \\
\text { sāhib al-māl or the rabb al-māl (the } \\
\text { financier), provides a specified } \\
\text { amount of capital and acts like a } \\
\text { sleeping or dormant partner, while } \\
\text { the other party, called the mudārib } \\
\text { (entrepreneur), provides the } \\
\text { entrepreneurship and management } \\
\text { for carrying on any venture, trade, } \\
\text { industry or service with the } \\
\text { objective of earning profits } \\
\text { (Chapra, 1997) }\end{array}$ & Mudharabah & $\begin{array}{lr}\text { Financial } & \text { Services } \\
\text { Authority } & \text { (OJK), } \\
\text { January 2012-Mei 2016 }\end{array}$ \\
\hline Musharakah (MS) & $\begin{array}{l}\text { Shirkah (or sharikah) refers to } \\
\text { partnership between two or more } \\
\text { persons whereby, unlike } \\
\text { mudārabah, all of them have a } \\
\text { share in finance as well as } \\
\text { entrepreneurship and management, } \\
\text { though not necessarily equally } \\
\text { (Chapra, 1997) }\end{array}$ & Musharakah & $\begin{array}{lr}\begin{array}{l}\text { Financial } \\
\text { Authority }\end{array} & \begin{array}{r}\text { Services } \\
\text { (OJK), }\end{array} \\
\text { January 2012-Mei 2016 }\end{array}$ \\
\hline $\begin{array}{ll}\text { Interest } & \text { rate } \\
\text { (BIRATE) } & \end{array}$ & $\begin{array}{l}\text { Payments for the use of money } \\
\text { expressed as a percentage of the } \\
\text { purchase price or principal of loan, } \\
\text { bond, or other financial instrument } \\
\text { (Hoover, 2012). }\end{array}$ & BI Rate & $\begin{array}{lll}\text { bank } & \text { of } & \text { Indnesia } \\
\text { January } & 2012-\text { May } \\
2016 & & \end{array}$ \\
\hline
\end{tabular}

Source: Researcher from many sources (2018).

\section{Result and Discussion}

\subsection{Descriptive Statistics}

Descriptive statistic is defined as a number that convey a particular characteristic of a set of data (Spatz, 2008). In this research, there are inflation, national sukuk, mudharabah, musharakah, and interest rate which are presented in table below.

Table 3. Descriptive statistic

\begin{tabular}{lrrrrr}
\hline & $\begin{array}{c}\text { Inflation (\% } \\
\text { CPI) }\end{array}$ & $\begin{array}{c}\text { Sukuk } \\
\text { (Billion } \\
\text { Rupiah) }\end{array}$ & $\begin{array}{c}\text { Mudharabah } \\
\text { (Billion } \\
\text { Rupiah) }\end{array}$ & $\begin{array}{c}\text { Musharakah } \\
\text { (Billion } \\
\text { Rupiah) }\end{array}$ & $\begin{array}{c}\text { Interest } \\
\text { rate } \\
(\%)\end{array}$ \\
\hline Mean & 5,82 & 140,04 & 13,27558 & 41,37011 & 6,83 \\
\hline Median & 5,57 & 132,29 & 13,802 & 40,583 & 7,25 \\
\hline Range & 5,46 & 198,97 & 5,69 & 45,757 & 2 \\
\hline Minimum & 3,33 & 61,28 & 10,039 & 18,759 & 5,75 \\
\hline Maximum & 8,79 & 260,26 & 15,729 & 64,516 & 7,75 \\
\hline Sum & 308,49 & 7422,07 & 703,606 & 2192,616 & 362,25 \\
\hline Count & 53 & 53 & 53 & 53 & 53 \\
\hline
\end{tabular}

Source: Researcher, 2018 
From descriptive statisctics above, the highest level of inflation is $8,79 \%$ and the lowest rate is $3,33 \%$, summing up all the data, the total of inflation from observation date is $308,49 \%$ with average rate (mean) is $5,82 \%$. For national sukuk, The highest level is 260,2 billion rupiah, the lowest level is 61 billion rupiah, and the total of national sukuk is 7422,07 billion rupiah with average rate (mean) is 140,04 billion rupiah. highest level of mudharabah is 15,72 billion rupiah and the lowest one is 10,03 billion rupiah whereas the highest level of musharakah is 64,51 and the lower one is 18,75 billion rupiah, summing up all the data, the total level of mudharabah from observation date is 703,606 billion rupiah and 2192,61 for musharakah with average rate (mean) is 13,27 for mudharabah and 41,37 for musharakah.

In Interest rate, the highest level of interest rate is $7,75 \%$ and the lowest rate is $5,75 \%$, summing up all the data, the total of interest rate from observation date is $362,25 \%$ with average rate (mean) is $6,83 \%$. For the measurement of dispersion, range that measure the difference between the greatest and the smallest (Mirer, 1995) in inflation data set shows 5,46 per cent, national sukuk is 198,97 billion rupiah, mudharabah is 5,69 billion rupiah, 45,76 billion rupiah for musharakah and interest rate is 2 per cent. .

The value of the middle observation of inflation, national sukuk, mudharabah, musharakah, and interest rate after the observations have been ordered from smallest to largest (Mirer, 1995) or, median value, is 5,57\% for inflation, 132,29 billion rupiah for national sukuk, 13,8 billion rupiah for mudharabah, 40,6 billion rupiah for musharakah, and 7,25 per cent for interest rate. For studying the "shape" of a probability distribution, then skewness and kurtosis is used (Gujarati and Porter, 2009)

\subsection{Unit Root Test}

Akeike Information Criterion (AIC) is employed to gain the lag length in ARDL approach automatically with maximum lag pegged to 7 . From AIC, the optimal length for lag is ARDL $(5,6,7,6,7)$ as depicted in Table 4 below.

Table 4. AIC for model selection

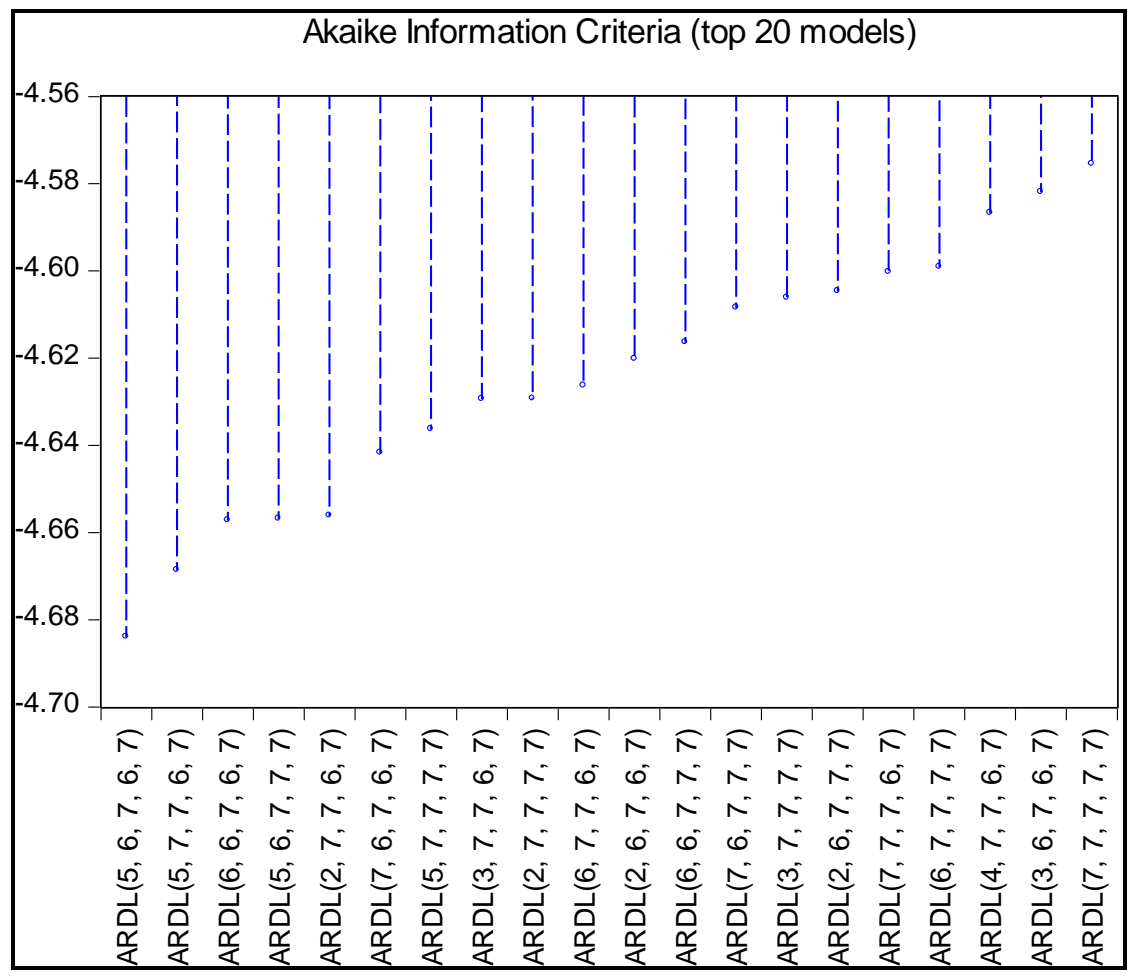

Source: Researcher, 2018 (Computed with Eviews 9)

Furthermore, the result of ADF test for each variables is presented as follow. 
Table 5. Unit root testing using the ADF test

\begin{tabular}{|c|c|c|c|c|}
\hline \multirow{2}{*}{ Variable } & \multirow{2}{*}{ Model } & \multicolumn{2}{|c|}{$\begin{array}{l}\text { Augmented Dickey-Fuller } \\
(\mathrm{ADF}) \text { test }-\mathrm{t} \text { stat. }\end{array}$} & \multirow{2}{*}{ Decision } \\
\hline & & Levels & $\begin{array}{c}\text { First } \\
\text { Difference }\end{array}$ & \\
\hline \multirow[t]{3}{*}{ Inflation } & Intercept & $-2,367$ & $-5,244 * * *$ & $\mathrm{I}(1)$ \\
\hline & Intercept and Trend & $-2,081$ & $-5,661 * * *$ & $\mathrm{I}(1)$ \\
\hline & none & $-0,342$ & $-5.297 * * *$ & $\mathrm{I}(1)$ \\
\hline \multirow[t]{3}{*}{ National sukuk } & Intercept & $-1,066$ & $-7,811 * * *$ & $\mathrm{I}(1)$ \\
\hline & Intercept and Trend & $-3,549$ & $-7,775 * * *$ & $\mathrm{I}(1)$ \\
\hline & none & $-3,237$ & $-6,402 * * *$ & $\mathrm{I}(1)$ \\
\hline \multirow[t]{3}{*}{ Mudharabah } & Intercept & $-2,098$ & $-4,744 * * *$ & $\mathrm{I}(1)$ \\
\hline & Intercept and Trend & $-2,233$ & $-4,935 * * *$ & $\mathrm{I}(1)$ \\
\hline & none & 1,865 & $-4,259 * * *$ & $\mathrm{I}(1)$ \\
\hline \multirow[t]{3}{*}{ Musharakah } & Intercept & $-3,196 * *$ & $-5,907 * * *$ & $\mathrm{I}(1)$ \\
\hline & Intercept and Trend & $-1,151$ & $-6,865 * * *$ & $\mathrm{I}(1)$ \\
\hline & none & 8,587 & $-2,059 * *$ & $\mathrm{I}(1)$ \\
\hline \multirow[t]{3}{*}{ Interest rate } & Intercept & $-1,999$ & $-3,778 * * *$ & $\mathrm{I}(1)$ \\
\hline & Intercept and Trend & $-1,216$ & $-4,071 * *$ & $\mathrm{I}(1)$ \\
\hline & none & 0,641 & $-3,732 * * *$ & $\mathrm{I}(1)$ \\
\hline
\end{tabular}

$(* * *),(* *),(*)$, indicate $1 \%, 5 \%$, and $10 \%$ level of significance, respectively

Source: Researcher's own computation, 2018 (Using Eviews 9)

Since the data are integrated of order $1, \mathrm{I}(1)$, and there is no data that has $\mathrm{I}(2)$, then ARDL bounds test can be performed to analyse these variables in this research.

4.3 Test for Co-integration

Table 6. ARDL Bounds Test

Null Hypothesis: No long-run relationships exist

\begin{tabular}{lcc}
\hline Test Statistic & Value & $\mathrm{k}$ \\
\hline F-statistic & 15.43679 & 4 \\
\hline Critical Value Bounds & & \\
\hline Significance & I0 Bound & I1 Bound \\
\hline $10 \%$ & 2.45 & 3.52 \\
$5 \%$ & 3.79 & 4.01 \\
$2.5 \%$ & 3.25 & 4.49 \\
$1 \%$ & 5.15 & 5,06 \\
\hline
\end{tabular}

Source: Researcher's own computation (Using Eviews 9) 
Based on that result, to reject null hypothesis, value of F-statistics must be above upper bound proposed by the system. F-statistics shows 15,44 , higher than upper bound 5,06 at the $1 \%$ level of significance, meaning that $\mathrm{H}_{0}$ can be rejected or it can be concluded based on the general level relation that there is a general level relation among national sukuk, mudharabah, musharakah and interest rate on inflation in Indonesia, or the model is co-integrated, or has long run relationship simultaneously.The result supports Chishti (1985)'s theory where PLS can affect inflation, where in this research PLS is proxied with national sukuk, mudharabah, and musharakah. Furthermore, to prove that inflation that comes from PLS is more stable than inflation that comes from interest rate in the long run, equation two and three will be employed.

\subsection{Test for Short Run and Long Run}

To prove whether PLS will bring stable inflation than interest rate, this paper uses sensitivity analysis where if coefficient of PLS - inflation is less than coefficient of interest rate - inflation, then it can be said that PLS is more stable than interest rate. Then, as the model in equation 1 is co-integrated, equation 2 and 3 will be analysed to know the long run and short run relationship individually for testing the H-2 hypotheses and to see the coefficient. Based on the theory, PLS will bring more stable level of inflation than interest rate. Table below shows the result.

Table 7. The long run and short run coefficient

\section{Long run}

ARDL $(5,6,7,6,7)$ selected by Akeike Information Criterion

Dependent variable is inf (Inflation)

\begin{tabular}{|c|c|c|c|c|c|}
\hline Regressor & & Coefficient & Standard Error & T-Statistics & P-value \\
\hline Ln NS (National Sukuk) & & $-2,52$ & 0,72 & $-3,49$ & 0,005 \\
\hline Ln MD (Mudharabah) & & 13,178 & 1,71 & 7,707 & 0,000 \\
\hline Ln MS (Musharakah) & & $-1,233$ & 0,746 & $-1,651$ & 0,129 \\
\hline Ln BIRATE (Interest rate) & & $-6,173$ & 1,488 & $-4,148$ & 0,002 \\
\hline C (Constanta) & & $-72,88$ & 9,65 & $-7,55$ & 0,000 \\
\hline \multicolumn{6}{|c|}{ The short run coefficient with Error Correction Model } \\
\hline Regressor & & Coefficient & Standard Error & T-Statistics & P-value \\
\hline$\Delta$ Ln NS (National Sukuk) & & $-0,468$ & 0,373 & $-1,252$ & 0,238 \\
\hline$\Delta \operatorname{Ln}$ MD (Mudharabah) & & 4,177 & 0,99 & 4,19 & 0,001 \\
\hline$\Delta$ Ln MS (Musharakah) & & $-2,564$ & 1,019 & $-2,516$ & 0,03 \\
\hline$\Delta$ Ln BIRATE (Interest rate) & & 2,666 & 0,94 & 2,831 & 0,017 \\
\hline $\mathrm{ECT}_{\mathrm{t}-1}$ & & $-0,97$ & 0,227 & $-4,267$ & 0,001 \\
\hline R-squared & 0,970 & & Mean dependent var & $-0,002$ & \\
\hline Adjusted R-squared & 0,860 & & S.D. Dependent var & 0,06 & \\
\hline S.E or regression & 0,020 & & Akaike info criterion & $-4,68$ & \\
\hline Sum Squared Resid & 0,005 & & Schwarz criterion & $-3,25$ & \\
\hline Log Likelihood & 143,7 & & Hannan-Quinn Criter & $-4,14$ & \\
\hline F-statistics & 9,270 & & Durbin-Watson stat & 4,58 & \\
\hline Prob (F-Stat.) & 0,000 & & & & \\
\hline
\end{tabular}

ect $=$ inflation $+2,52 *$ National sukuk $-13,17 *$ Mudharabah $+1,233 *$ Musharakah

$+6,17 *$ interest rate $+72,88 *$ Intercept)

Source: Researcher's own computation, 2018 (Using Eviews 9). 
From above empirical result, some diagnostic tests result is presented in below table to see some econometric problem.

Table 8. Diagnostic tests

\begin{tabular}{llrr}
\hline item & test applied & CHSQ & \multicolumn{1}{c}{ Prob } \\
\hline Serial Correlation & Breusch-Godfrey Serial Correlation & 0,152 & 0,00 \\
Normality & Jarque-Bera & 1,305 & 0,52 \\
Functional form & Ramsey's RESET & 0,012 & 0,99 \\
Heteroscedasticity & Breusch-Pagan-Godfrey & 0,402 & 0,371 \\
\hline
\end{tabular}

Source: Researcher, 2018

Above result of diagnostic result shows that the model indicates autocorrelation problem. However, following Hasan and Nasir (2008), problem like autocorrelation is conflicting to normal distribution that has not been observed. Furthermore, there is no model specification error, and also there is no precence of heteroscedastiscity in the model.

For the estimated result in Table 7, in the short run, the table above shows that error correction has the negative sign and significant at $1 \%$ level of significance, meaning that adjustment process of the disequilibrium in the short run will be fixed (eliminated) in the long run (Hasan and Nasir, 2008) for about 97\%. Following Ariefianto (2012) to intrepret ECT coefficient, the disequilibrium in the short run will be fixed to the equilibrium in the long run for about 1,03 mounth $(1 / 0,97)$.

In the short run, PLS which is proxied by only mudharabah and musharakah can affect inflation. Based on sensitivity analysis, in the short run, only PLS proxied by musharakah can stabilise inflation rather than interest rate as coefficient value of musharakah is less than interest rate. In the long run, PLS proxied by national sukuk, and mudharabah can affect inflation and based on their sensitivity, only National sukuk that can be used to stabilise inflation since its coefficient is less than interest rate.

Therefore, based on the short-and long run coefficient, PLS that proxied by national sukuk can stabilise level of inflation in the long run only, but not in the short run. PLS that is proxied by Musharakah can stabilise inflation in the short run only but not in the long run. Mudharabah, eventhough significant both in the long run and short run, but its coefficient shows that the instrument is highly sensitive to inflation compared to interest rate, and cannot be used to stabilise inflation in the short run and long run.

\subsection{Stability Test for Parameter}

Furthermore, to test whether the regression coefficients are generally stable over the sample period (Omar, Hussin and Ali GH, 2015), Hasan and Nasir (2008) used CUSUM and CUSUMSQ plots. The plots are depicted as follow.

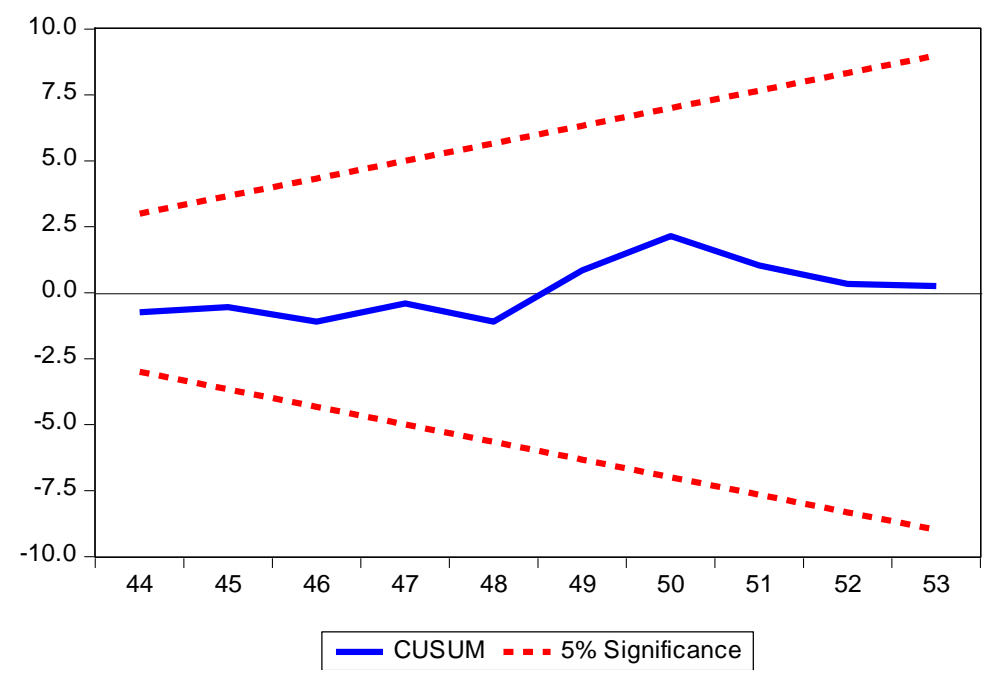




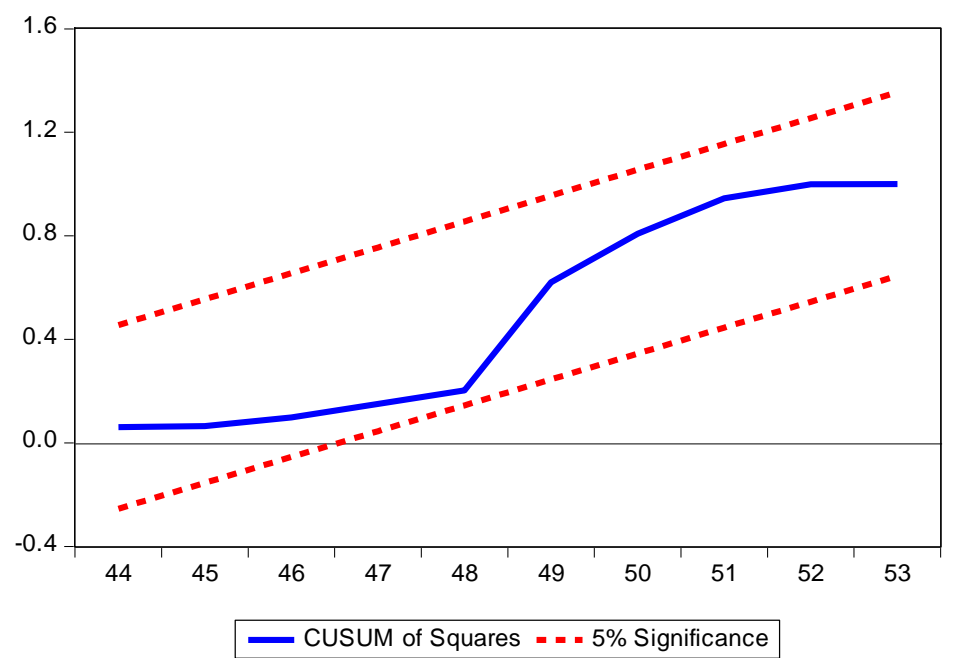

As depicted above, Hasan and Nasir (2008) explained that when CUSUM and CUSUMSQ are within the critical bounds of $5 \%$, it indicates that the model is structurally stable. The result shows that CUSUM and CUSUMSQ are within the red line with $5 \%$ level of significance, meaning that the model is structurally stable.

\section{Conclusion}

This paper try to see the relationship between PLS and inflation that theoritically PLS can stabilise level of inflation rather than interest rate in Indonesia. Based on bound test, it can be concluded that PLS proxied by National sukuk, mudharabah and musharakah and interest rate simultaneously affect inflation in Indonesia. Based on coefficient value analysis, PLS that is proxied by national sukuk can stabilise level of inflation in the long run only, but not in the short run. Musharakah as other proxy of PLS can stabilise inflation in the short run only but not in the long run. However, Mudharabah cannot be used to stabilise inflation both the short run and long run. Based on this result, this paper suggests that Bank of Indoesia as the main authority to control inflation can utilise sukuk instrument to stabilise level of inflation rather than depends only on BI rate. Furthermore, for the further research, the hypothesis of PLS that can stabilise inflation can be proved by broaden the scope of data such as including some others Moslem majority countries and compare it with non-Moslem majority countries.

\section{References}

Acaravci, S.K., Acaravci, A., \& Ozturk, I. (2011). Stock Returns and Inflation Nexus in Turkey: Evidence from ARDL Bounds Testing Approach. Economic Computation and Economic Cybernetics Studies and Research, 3.

Aiyagari, S.R. (1990). Deflation the case for zero inflation. Quarterly Review Federal Reserve Bank of Minneapolis, $3(14), 1-11$.

Akmal, M.S. (2007). Stock Returns and Inflation: An ARDL Econometric Investigation Utilizing Pakistani Data. Pakistan Economic and Social Review, 45(1), 89-105.

Anari, A., \& Kolari, J. (2016). Dynamic of Interest and Inflation Rate, Journal of Empirical Finance, 39, $129-144$. https://doi.org/10.1016/j.jempfin.2016.08.008

Ariefianto, M.D. (2012). Ekonometrika: Esensi dan Aplikasi dengan Menggunakan Eviews. Jakarta, Penerbit Erlangga.

Ariff, M. (2015). Appeal of Sukuk as a New Type of Financial Instrument. JKAU:Islamic Econ., 28(2), 149-175.

Ascarya. (2017). The real Determinations of Financial Crisis and How to Resolve it in Islamic Economics Percpective. International Journal of Economic Research, 14(13), 501-531.

Blanchard, O. (1997). Macroeconomics: International Edition. New Jersey, Prentice-hall.

Booth, G.G., \& Ciner, C. (2001). The relationship between nominal interest rates and inflation: International evidence. Journal of multinational financial management, $11, \quad 269-280$. https://doi.org/10.1016/S1042-444X(01)00030-5

Chapra, M.U. (1997). Al Qur'an Menuju sistem moneter yang adil. Yogyakarta, Dana Bhakti Prima Yasa.

Chishti, S.U. (1985). Relative Stability of Interest-Free Economy. J.Res Islamic Econ., 3(1), 3-12. 
Deaton, A. (2015). Consumption, Poverty and Welfare. The Royal Swedish Academy of Science, October 12.

Demary, M., \& Huther, M. (2015). When low interest rates cause low inflation. Intereconomics, 350-355. https://doi.org/10.1007/s10272-015-0559-6

Froyen, R.T. (2013). Macroeconomics: Theories and Policies (10th ed.). Essex, Pearson Education Limited.

Gujarati, D.N., \& Porter, D.C. (2009). Basic Econometrics (5th ed.). New York, McGraw-Hill Irwin.

Hasan, A., \& Nasir, Z.M. (2008). Macroeconomic factors and equity prices: An empirical investigation by using ARDL approach. The Pakistan Development Review, 47(4), Part II, 501-513. https://doi.org/10.30541/v47i4IIpp.501-513

Hoover, K.D. (2012). Applied Intermediate Macroeconomics. United Stated of America, Cambridge University Press.

Kenward, L. R. (2013). Inflation Targeting in Indonesia, 1999-2012: An Ex-post Review. Bulletin of Indonesian Economics Studies, 3(49), 305-327. https://doi.org/10.1080/00074918.2013.850630

Krishnamurthy, S., Pelletier, D., \& Warr, R.S. (2018). Inflation and equity mutual fund flows. Journal of financial markets, 37, 52-69. https://doi.org/10.1016/j.finmar.2017.12.001

Lee, K.F. (2007). An empirical study of fisher effect and the dynamic relation between nominal interest rate and inflation in Singapore. Munich Personal RePec Archive. Retrieved from http://mpra.ub.uni-muenchen.de/12383/

Linnemann, L. (2005). Can raising interest rates increase inflation?. Economic Letters, 87, 307-311. https://doi.org/10.1016/j.econlet.2004.12.020

Mankiw, N. G. (2012). Macroeconomics (8th ed.). Worth Publisher, New York.

Mirer, T.W. (1995). Economic statistics and econometrics (3rd ed.). New Jersey, Prentice-Hall.

Nishizaki, K., \& Watanabe, T. (2000). Output-Inflation Trade-Off at Near-Zero Inflation Rate. Journal of the Japanese and International Economics, (14), 304-326. https://doi.org/10.1006/jjie.2000.0451

O'neill, R., Ralph, J., \& Smith, P. A. (2017). Inflation: History and Measurement. Hampshire, Palgrave Macmillan. https://doi.org/10.1007/978-3-319-64125-6

Obradovic, S., \& et al.. (2017). Linkages between Inflation and Economic Growth in Serbia: An ARDL Bounds Testing Approach. Inzinerine Ekonomika-Engineering Economics, 28(4), 401-410.

Omar, W.A.W., Hussin, F., \& Ali GH, A. (2015). The Empirical Effects of Islam on Economic Development in Malaysia. Research in World Economy, 6(1), 99-111.

OpenStax. (2014, March 19). Macroeconomics. OpenStax. Retrieved from http://cnx.org/content/col11626/latest/

Pesaran, M.H., Shin, Y., \& Smith, R,J. (2001). Bounds Testing Approaches to The Analysis of Level Relationships. Journal of Applied Econometrics, 16, 289-326. https://doi.org/10.1002/jae.616

Rushdi, M., Kim, J.H., \& Silvapulle, P. (2012). ARDL Bounds Tests and robust inference for the long run relationship between real stock returns and inflation in Australia. Economic Modelling, 29, 535-543. https://doi.org/10.1016/j.econmod.2011.12.017

Shahbaz, M., Islam, F., \& Rehman I.U. (2016). Stocks as Hedge against Inflation in Pakistan: Evidence from ARDL Approach. Global Business Review, 17(6), 1-16. https://doi.org/10.1177/0972150916660393

Spatz, C. (2008). Basic Statistics: Tales of Distributions (9th ed.). Belmont, Thomson-Wadsworth.

Sunel, E. (2018). Welfare consequences of gradual disinflation in emerging economies. Journal of money, credit, and banking, 50(4), 705-755. https://doi.org/10.1111/jmcb.12478

Wolman, A.L. (1997). Zero inflation and the friedman rule: A welfare comparison. Economic Quarterly - Federal Reserve Bank of Richmond, 83(4), 1-21.

\section{Note}

Note 1. Taken from detik finance online news (Indonesian language), see:

https://finance.detik.com/berita-ekonomi-bisnis/d-4140819/bps-beberkan-angka-kemiskinan-dari-masa-ke-masa 